\title{
Surgical treatment of pulmonary atresia with intact ventricular septum
}

\author{
George A. Trusler, Noriaki Yamamoto, William G. Williams, Teruo Izukawa, \\ Richard D. Rowe, and William T. Mustard \\ From the Departments of Surgery and Pediatrics, the Hospital for Sick Children, Toronto, and the University \\ of Toronto, Canada
}

Fifty-nine children with pulmonary atresia and intact ventricular septum underwent various forms of surgical treatment at the Hospital for Sick Children, Toronto, during 1950 to mid 1975. Twenty-three patients had pulmonary valvotomy, 15 direct, 2 indirect, and 6 both direct valvotomy and infundibulectomy. All died, 19 early and 4 late. Of 13 patients who received a systemic-pulmonary artery shunt, 4 combined with surgical atrial septectomy, there are only 2 long-term survivors both of whom were children who had had a Waterston anastomosis.

Recently we have been treating infants with small right ventricles with balloon atrial septostomy at cardiac catheterization followed by a Potts anastomosis and pulmonary valvotomy. If the Potts anastomosis appears satisfactory the persistent ductus arteriosus is ligated. This scheme was used in 23 infants, with 4 early deaths and 2 late deaths. Of 17 survivors, further shunts were required in 4 children. One child has had a formal repair, with insertion of valves in both tricuspid and pulmonary areas. We believe that this operative combination of Potts anastomosis and pulmonary valvotomy offers the infant with pulmonary atresia and a small right ventricle a relatively low initial mortality and the possibility of right ventricular enlargement and subsequent repair.

Pulmonary atresia with intact ventricular septum is an uncommon anomaly representing 1 per cent of the total group of congenital cardiac malformations (Keith, Rowe, and Vlad, 1967). The defect is characterized by complete anatomical obstruction of blood flow from the right ventricle to the pulmonary trunk by an imperforate pulmonary valve. Systemic venous blood returning to the heart bypasses the right ventricle through an interatrial communication. Survival depends upon the persistent ductus arteriosus maintaining sufficient pulmonary blood flow; duct closure results in death. Emergency palliative operations have often been attempted but the results have until recently been poor (Gersony et al., 1967; Bowman et al., 1971; Cole et al., 1968; Moller et al., 1970).

In this paper, we report our experience with the operative treatment of pulmonary atresia with intact ventricular septum over the past 25 years.

Received 5 December 1975. 
TABLE 1 Age at operation in 59 patients

\begin{tabular}{ll}
\hline Age at operation & Number of patients \\
\hline 0-2nd week & 39 \\
2nd-4th week & 9 \\
1-6 months & 6 \\
$>6$ months & 5 \\
\hline
\end{tabular}

of the persistent ductus arteriosus. Ten patients also had a pulmonary valvotomy at the same operation. All but one of the 23 had a balloon atrial septostomy (Rashkind and Miller, 1966) at the time of diagnostic catheterization.

\section{Results}

Of the 15 patients who had direct pulmonary valvotomy with inflow occlusion, 13 died in the early postoperative period and 2 later. The longest survival time, 4 years, was related more to persistent patency of ductus arteriosus than to the opening of the pulmonary valve. In 4 patients who died, the right ventricle was of moderate or large size; 2 patients survived indirect pulmonary valvotomy (Brock procedure) for $2 \frac{1}{2}$ months and 8 months, respectively; 6 patients had direct valvotomy plus infundibulectomy and all died in the early postoperative period.

Nine patients received various types of systemic artery-pulmonary artery shunts. Though 7 died, 2 children who had Waterston shunts were still alive at follow-up. One of these had a pulmonary valvotomy four years after the shunt. In 4 other children a right-sided arterial shunt was combined with open creation of an atrial septal defect using inflow venous occlusion. These children were operated on before the technique of balloon atrial septostomy was described and all 4 died, either at operation or shortly after.

More recently, 23 patients had a Potts left aortopulmonary anastomosis and 10 of these also had a pulmonary valvotomy. This was usually combined with ductus ligation and preceded by a balloon atrial septostomy (Table 3). Nineteen patients survived and 4 died. Subsequently, 2 children survived cavopulmonary anastomosis (Glenn, 1958) and pulmonary valvotomy 51 months and 22 months later. Two other children required additional systemic artery-pulmonary artery shunts. One had a right Blalock-Taussig anastomosis combined with a pulmonary valvotomy six years later and the other a Waterston anastomosis and a Blalock-Hanlon atrial septectomy 20 months later. Three patients underwent pulmonary valvotomy in the late follow-up period, with 2 deaths, the only late deaths in this group. The third child survived, and in March 1974, 2 months after the pulmonary valvotomy, a repair was done in which the pulmonary and tricuspid valves were replaced with Hancock porcine valves and the right ventricular outflow tract was patched. The Potts anastomosis was closed but the atrial septal defect was left partly open because of the questionable size of the right ventricle. This patient is mildly cyanosed but doing well. There were 17 survivors in this group of 23 at the time of follow-up.

\section{Discussion}

The size of the right ventricle has been used to classify this clinical entity into two categories (Davignon et al., 1961). In one, the right ventricle is dimunitive or hypoplastic and in the second category the right ventricle is large. Variability exists between the two extremes (Gersony et al., 1967; Bowman et al., 1971; Murphy et al., 1971). For those infants with a normal or large ventricular cavity, pulmonary valvotomy is said to be the operation of choice (Gersony et al., 1967; Murphy et al., 1971), though our experience suggests that

TABLE 2 Experience with pulmonary atresia with intact ventricular septum

\begin{tabular}{|c|c|c|c|c|}
\hline \multirow[t]{2}{*}{ Operative procedure } & \multirow{2}{*}{$\begin{array}{l}\text { Number of } \\
\text { patients }\end{array}$} & \multicolumn{2}{|l|}{ Deaths } & \multirow[t]{2}{*}{ Survivors } \\
\hline & & Early & Late & \\
\hline Pulmonary valvotomy & 23 & & & \\
\hline Direct & 15 & 13 & 2 & 0 \\
\hline Indirect (Brock procedure) & 2 & 0 & 2 & 0 \\
\hline Direct plus infundibulectomy & 6 & 6 & 6 & 0 \\
\hline Systemic-pulmonary artery shunt & 13 & & & \\
\hline Shunt alone & 9 & 7 & 0 & 2 \\
\hline Shunt plus surgical septostomy & 4 & 4 & 0 & 0 \\
\hline $\begin{array}{l}\text { Balloon atrial septostomy, Potts anastomosis, and ductus ligation } \\
\text { (with pulmonary valvotomy } 10 \text { patients) }\end{array}$ & 23 & 4 & 2 & 17 \\
\hline Total & 59 & 34 & 6 & 19 \\
\hline
\end{tabular}


TABLE 3 Clinical material and results in 23 patients who underwent balloon atrial septostomy, Potts anastomosis, and persistent ligation of ductus arteriosus

\begin{tabular}{|c|c|c|c|c|}
\hline $\begin{array}{l}\text { Case No., } \\
\text { sex, and } \\
\text { age (d) }\end{array}$ & $\begin{array}{l}\text { Date of } \\
\text { operation }\end{array}$ & Remarks & Early results & Late results, follow-up \\
\hline $\begin{array}{l}1, M, 2 \\
2, F, 19\end{array}$ & $\begin{array}{l}23 / 12 / 67 \\
5 / 3 / 68\end{array}$ & & & $\begin{array}{l}\text { Mild cyanosis } \\
\text { Cavopulmonary anastomosis, pulmonary } \\
\text { valvotomy } 21 / 6 / 72 ; \text { moderate cyanosis }\end{array}$ \\
\hline $\begin{array}{l}3, M, 1 \\
4, F, 5\end{array}$ & $\begin{array}{l}17 / 5 / 68 \\
13 / 6 / 68\end{array}$ & Normal RV & Died 2nd postop day & $\begin{array}{l}\text { Cavopulmonary anastomosis, pulmonary } \\
\text { valvotomy } 1 / 5 / 70 ; \text { moderate cyanosis }\end{array}$ \\
\hline $5, F, 5$ & $12 / 11 / 68$ & & & $\begin{array}{l}\text { Right Blalock-Taussig anastomosis, } \\
\text { pulmonary valvotomy } 17 / 4 / 75 \text {; moderate } \\
\text { cyanosis, congestive heart failure }\end{array}$ \\
\hline $6, M, 4$ & $19 / 1 / 70$ & & & $\begin{array}{l}\text { Pulmonary valvotomy, } 11 / 1 / 73 \text {; total repair } \\
20 / 3 / 74 \text {; mild cyanosis, congestive heart } \\
\text { failure } 20 / 3 / 74\end{array}$ \\
\hline $7, F, 1$ & $21 / 8 / 70$ & & & $\begin{array}{l}\text { Pulmonary valvotomy } 26 / 10 / 71 \text {; died at } \\
\text { operation }\end{array}$ \\
\hline $8, M, 2$ & $28 / 8 / 70$ & No BAS & & Normal activity; mild cyanosis \\
\hline $\begin{array}{l}9, F, 8 \\
10, M, 7\end{array}$ & $\begin{array}{l}22 / 1 / 71 \\
12 / 7 / 71\end{array}$ & & Died 3rd poston day & Marked cyanosis \\
\hline $11, F, 1$ & $16 / 6 / 71$ & Pulmonary valvotomy & & Mild cyanosis \\
\hline $12, M, 2$ & $28 / 10 / 71$ & Pulmonary valvotomy & & Mild cyanosis; normal activity \\
\hline $13, M, 4$ & $10 / 1 / 72$ & Pulmonary valvotomy & Died at operation & \\
\hline $14, F, 6$ & $2 / 2 / 72$ & & & $\begin{array}{l}\text { Pulmonary valvotomy } 23 / 8 / 73 \text {, died at } \\
\text { operation }\end{array}$ \\
\hline $15, \mathrm{~F}, 0$ & $27 / 5 / 72$ & Pulmonary valvotomy & Died at operation & \\
\hline $16, M, 1$ & $4 / 4 / 72$ & Pulmonary valvotomy & & Moderate cyanosis \\
\hline $17, F, 2$ & $4 / 6 / 73$ & Pulmonary valvotomy & & Mild cyanosis \\
\hline $18, F, 1$ & $19 / 6 / 73$ & Pulmonary valvotomy & & $\begin{array}{l}\text { Waterston anastomosis, Blalock-Hanlon } \\
\text { septectomy } 4 / 3 / 75 \text {, moderate cyanosis }\end{array}$ \\
\hline $19, M, 1$ & $22 / 11 / 73$ & & & Mild cyanosis \\
\hline $20, F, 2$ & $23 / 2 / 74$ & & & Moderate cyanosis \\
\hline $21, F, 0$ & $10 / 12 / 74$ & Pulmonary valvotomy & & Moderate cyanosis, congestive heart failure \\
\hline $22, F, 44$ & $14 / 12 / 75$ & Pulmonary valvotomy & & Moderate cyanosis \\
\hline $23, F, 1$ & $8 / 5 / 75$ & Pulmonary valvotomy & & Mild cyanosis \\
\hline
\end{tabular}

a more extensive repair is often necessary. The tricuspid valve is usually abnormal, and this may be a limiting factor in early primary repair. The majority of the patients, $54(92 \%)$ in our series, have a hypoplastic thick-walled right ventricle (Gersony et al., 1967; Cole et al., 1968; Shams et al., 1971) with a cavity which varies from diminutive to small. Our early experience (Trusler and Fowler, 1970) and that of others (Bowman et al., 1971; Murphy et al., 1971; Miller et al., 1973) suggests that a pulmonary valvotomy and/or infundibulectomy fail in this group because the tiny right ventricular cavity and narrow infundibular canal are incapable of accommodating adequate blood flow.

A systemic-pulmonary artery shunt, in theory, should improve children with small right ventricles. We have 2 long-term survivors who received a Waterston anastomosis. Bowman et al. had better long-term results when a systemic artery-pulmonary artery shunt was combined with pulmonary valvotomy.
Pulmonary atresia with intact ventricular septum and hypoplastic right ventricle is similar haemodynamically to tricuspid atresia with inadequate pulmonary blood flow. In both an adequate interatrial communication is essential to ensure right atrial exit. A balloon atrial septostomy followed by a systemic-pulmonary artery shunt has been successful in the palliative management of tricuspid atresia (Rashkind et al., 1969). We have managed patients with pulmonary atresia and intact ventricular septum in this way since 1967 (Shams et al., 1971; Trusler and Fowler, 1970). A balloon atrial septostomy was performed as part of the initial diagnostic cardiac catheterization on all patients but one and was followed soon after by Potts anastomosis and usually ligation of the persistent ductus arteriosus. Of 23 patients so treated there were only 4 early deaths, a mortality rate of 17 per cent.

Since 1971 , in 10 children, a transarterial pulmonary valvotomy was combined with these procedures not only to decompress the right ventricle 
but also in the hope that the combination of pulmonary regurgitation and a shunt would stimulate right ventricular enlargement (Moller et al., 1970; Bowman et al., 1971; Murphy et al., 1971). We prefer the Potts anastomosis for a number of reasons. The persistent ductus arteriosus can be ligated at the same operation if a suitable anastomosis is obtained, thus avoiding one factor that might cause excessive pulmonary blood flow. This may allow the operation to be performed more electively when the ductus is still large and the infant in relatively good condition. In our hands the Potts anastomosis has a higher rate of technical success and a better long-term prognosis than other shunts in early infancy. This is related to the smaller, thinner, more easily exposed descending aorta in comparison with the ascending aorta which would be used in the Waterston operation. Since we expect that some patients may benefit by subsequent cavopulmonary anastomosis (Edwards and Bargeron, 1968; Trusler, MacGregor, and Mustard, 1971) the left-sided shunt has the advantage that the right pleural space is not entered. If, on the other hand, the Fontan procedure proves to be safe and reliable over the long term for children with pulmonary atresia this will not be an advantage.

The diameter of the Potts anastomosis is an important long-term factor. It tends to enlarge with time, increasing pulmonary blood flow. To prevent excessive growth, the anastomosis is encircled or banded with a loose ring of number 2 silk. By this we hope to restrict the volume of shunt to an amount that will produce optimum palliation yet avoid heart failure and serious pulmonary vascular disease (Trusler and Kanzaki, 1973). A ring with a circumference of $25 \mathrm{~mm}$ allows the anastomosis to reach approximately $6 \mathrm{~mm}$ internal diameter. This seems adequate to perfuse the left lung ultimately should one decide to create a cavopulmonary anastomosis on the right. Further experience and longer followup is needed to confirm this.

Bowman et al. reported successful total repair in 2 patients who underwent palliation by systemicpulmonary artery shunt and pulmonary valvotomy. The right ventricular cavity was enlarged and the pulmonary outflow tract was reconstructed with an ellipse of aortic homograft bearing a single cusp. We have one similar repair using Hancock porcine valves in both tricuspid and pulmonary positions.

\section{References}

Bowman, F. O., Jr., Malm, J. R., Hayes, C. J., Gersony, W. M., and Ellis, K. (1971). Pulmonary atresia with intact ventricular septum. fournal of Thoracic and Cardiovascular Surgery, 61, 85.

Cole, R. B., Muster, A. J., Lev, M., and Paul, M. H. (1968). Pulmonary atresia with intact ventricular septum. American fournal of Cardiology, 21, 23.

Davignon, A. L., Greenwold, W. E., DuShane, J. W., and Edwards, J. E. (1961). Congenital pulmonary atresia with intact ventricular septum. Clinicopathologic correlation of two anatomic types. American Heart fournal, 62, 591.

Edwards, W. S., and Bargeron, L. M., Jr. (1968). The superiority of the Glenn operation for tricuspid atresia in infancy and chil thood. Fournal of Thoracic and Cardiovascular Surgery, $\mathbf{5 5}, 60$.

Gersony, W. M., Bernhard, W. F., Nadas, A. S., and Gross, R. E. (1967). Diagnosis and surgical treatment of infants with critical pulmonary outflow obstruction. Study of thirty-four infants with pulmonary stenosis or atresia, and intact ventricular septum. Circulation, 35, 765.

Glenn, W. W. L. (1958). Circulatory bypass of the right side of the heart. IV. Shunt between superior vena cava and distal right pulmonary artery-report of clinical application. New England fournal of Medicine, 259, 117.

Keith, J. D., Rowe, R. D., and Vlad, P. (1967). Heart Diseases in Infancy and Childhood, 2nd ed. Macmillan, New York.

Miller, G. A. H., Restifo, M., Shinebourne, E. A., Paneth, M., Joseph, M. C., Lennox, S. C., and Ken, I. H. (1973). Pulmonary atresia with intact ventricular septum and critical pulmonary stenosis presenting in first month of life. Investigation and surgical results. British Heart fournal, 35, 9.

Moller, J. H., Girod, D., Amplatz, K., and Varco, R. L. (1970). Pulmonary valvotomy in pulmonary atresia with hypoplastic right ventricle. Surgery, 68, 630.

Murphy, D. A., Murphy, D. R., Gibbons, J. E., and Dobell, A. R. C. (1971). Surgical treatment of pulmonary atresia with intact interventricular septum. Fournal of Thoracic and Cardiovascular Surgery, 62, 213.

Rashkind, W. J., and Miller, W. W. (1966). Creation of an atrial septal defect without thoracotomy. A palliative approach to complete transposition of the great arteries. Fournal of the American Medical Association, 196, 991.

Rashkind, W., Waldhausen, J., Miller, W., and Freidman, S. (1969). Palliative treatment in tricuspid atresia. Combined balloon atrioseptostomy and surgical alteration of pulmonary blood flow. Fournal of Thoracic and Cardiovascular Surgery, 57, 812.

Shams, A., Fowler, R. S., Trusler, G. A., Keith, J. D., and Mustard, W. T. (1971). Pulmonary atresia with intact ventricular septum: report of 50 cases. Pediatrics, 47, 370 .

Trusler, G. A., and Fowler, R. S. (1970). The surgical management of pulmonary atresia with intact ventricular septum and hypoplastic right ventricle. Fournal of Thoracic and Cardiovascular Surgery, 59, 740.

Trusler, G. A., and Kanzaki, Y. (1973). Controlling the growth of aortopulmonary anastamoses in piglets. Archives of Surgery, 106, 72.

Trusler, G. A., MacGregor, D., and Mustard, W. T. (1971). Cavopulmonary anastomosis for cyanotic congenital heart disease. Fournal of Thoracic and Cardiovascular Surgery, 62, 803.

Requests for reprints to George A. Trusler, F.R.C.S., Suite 1225, 123 Edward Street, Toronto, Ontario M5G 1G2, Canada. 